\title{
Residential demand for electricity: empirical evidence from Greece using pseudo-panels
}

\author{
Ioannis Kostakis $^{1,2}$ (1) $\cdot$ Sarantis Lolos ${ }^{3}$ \\ ${ }^{1}$ Department of Economics and Sustainable Development, Harokopio University, Athens, Greece \\ ${ }^{2}$ Hellenic Open University, Patras, Greece \\ ${ }^{3}$ Department of Economic and Regional Development, Panteion University, Athens, Greece
}

Received: 30 December 2020/Revised: 23 July 2021 / Accepted: 24 July 2021 / Published online: 4 August 2021

(c) The Joint Center on Global Change and Earth System Science of the University of Maryland and Beijing Normal University 2021

\begin{abstract}
This study investigates the behaviour of residential demand for electricity, employing a pseudo-panel methodology. The case of Greece, over the period 2009-2018, is taken as an example for our empirical investigation. The empirical analysis uses annual household panel data for the construction of 330 cohorts. The specification of cohorts is based on the date of birth, education level and geographical location of the head of the household. The econometric analysis is carried out using static and dynamic specifications and a quantile regression model. The results show that residential demand for electricity is price and income inelastic, both in the short and the long run. Electricity and heating oil appear to be complementary energy sources, while the household size and the education level are important determinants of residential demand for electricity. Income status has a marginal effect on demand for electricity, and the impact of urbanisation is insignificant. The quantile regression results show that, as the level of electricity use increases, demand for electricity becomes less income responsive and more price responsive. Our results show that a mix of structural energy measures along with economic policies could result in a decrease in electricity use and improve energy efficiency.
\end{abstract}

Keywords Residential demand for electricity · Price elasticity · Income elasticity · Pseudo-panel · Greece

JEL Classification R2 $\cdot \mathrm{Q} 4$

Ioannis Kostakis

ikostakis@hua.gr

\section{Introduction}

Greece has always been heavily dependent on fossil fuels, mainly lignite (coal) and oil. Electricity generation was dominated by lignite and oil (over 90\%) in the early 1990s. The energy mix for gross electricity generation has changed gradually, with fossil fuels accounting for $68 \%$ (lignite $32 \%$, oil $10 \%$, and natural gas $26 \%$ ) in 2018 , while the share of renewable energy sources and hydroelectric stations has increased significantly to $31 \%$. The respective shares in the EU-28 were $41 \%$ for fossil fuels, $34 \%$ for renewables and $25 \%$ for nuclear energy. In Greece, the reduction in lignite use was the greatest among European lignite-producing countries and although lignite use is still relatively high, greenhouse gas emissions decreased significantly (31\%) over the period 2005-2018, compared to a 17\% decrease in the EU-27 (European Commission 2020). In addition, the energy sector in Greece, as in other EU countries, has undergone major reforms by enhancing competition, restructuring state-owned companies and liberalising the electricity and natural gas markets. Furthermore, Greece is among the European countries planning to decarbonise the power sector well before 2030 .

European countries are facing the challenge of a substantial energy transition in order to achieve a sustainable, efficient and competitive energy system aimed at reducing energy dependency and greenhouse gas emissions. Greece followed the European trend in pursuing a new mix of cleaner fuel types. Besides its impressive increase in the share of renewables in electricity generation, surpassing the targets set for photovoltaic systems, the country has the potential to perform much better. Specific energy-related goals to be reached in Greece by 2030 are described in the Hellenic Republic (2019). Major changes are expected in 
the residential sector which accounts for more than $1 / 4$ of total energy consumption and over $1 / 3$ of electricity generation. The share of electricity in residential energy consumption is expected to increase from $37 \%$ in 2020 to $39 \%$ by 2030 . The corresponding share of renewables is expected to increase substantially from $27 \%$ in 2020 to $36 \%$ by 2030 . A contraction in the share of fossil fuels from $36 \%$ in 2020 to $25 \%$ by 2030 is also anticipated. Thus, electricity combined with renewable energy sources will play a central role as the dominant type of fuel in residential energy consumption $(75 \%)$.

In the new competitive energy environment, electricity as a source of energy will acquire qualitatively different characteristics from those of the past. This will be evident in the case of Greece, where electricity generation will move away from coal towards natural gas and renewables in the mainland and from oil towards renewable energy sources on the islands. The efficiency of the system will also improve via the interconnection of the Greek islands with the main grid and the promotion of energy efficient buildings. Furthermore, in the new environment, the installation of smart electricity meters will allow for a twoway connection between suppliers and final consumers. Note that renewable energy is primarily used for residential purposes $(73 \%)$. In view of the structural changes in electricity generation and electricity consumption that have occurred in European countries over the last decade, an examination of the responses of electricity to this change consumers is in order.

The purpose of this study is the investigation of residential demand for electricity, taking as an example the case of Greece over the period 2009-2018. Our paper contributes to the relevant literature in many respects. Firstly, to the best of our knowledge, it is the first empirical study that analyses residential demand for electricity using pseudo-panels constructed from disaggregated household data. Secondly, it employs a number of static, dynamic and quantile regression models and closes the gap between pseudo-panel and microeconomic panel analysis. It should be noted that existing empirical studies explore the behaviour of residential demand for electricity in Greece mostly at a macroeconomic level. Our main research question refers to the investigation of residential demand for electricity in the new energy environment. In particular, we formulate the following specific research hypotheses, based on demand theory:

(i) The price of electricity affects residential demand for electricity significantly.

(ii) Household income is a significant determinant of demand for electricity.

(iii) Heating oil is a complementary energy source to residential consumption of electricity. (iv) Socio-demographic and idiosyncratic characteristics are related to residential electricity consumption.

(v) Income and price responsiveness to demand for electricity is related to the level of electricity use.

The results of our empirical investigation provide useful insights for future energy developments and offer the basis for the evaluation and design of energy policies in other EU countries with similar characteristics.

The rest of the paper is structured as follows. Section 2 reviews the channels through which changes in prices, income and several socio-demographic parameters affect demand for electricity. Section 3 illustrates the situation of residential demand for electricity in Greece. Section 4 presents the methodological approach followed and the data used, while Sect. 5 discusses the empirical results. Concluding remarks and policy implications are presented in Sect. 6.

\section{Literature review}

Energy demand has been extensively investigated over the past decades (Kraft and Kraft 1978; Baker et al. 1989; Stern 2004; Ozturk 2010; Labandeira et al. 2017; Gozgor et al. 2018). Residential electricity consumption, in particular, has been analysed empirically in relation to economic, behavioural, personal, environmental and dwelling characteristics (Kavousian et al. 2013; Athukorala et al. 2019). Still, the main aim of the energy demand studies is the investigation of income and own-price elasticities (Fouquet 2014).

Numerous studies have investigated residential demand for electricity mostly for specific countries at an aggregate level using time series data (see, inter alia, Silk and Joutz 1997 for USA; Beenstock et al. 1999 for Israel; Hondroyiannis 2004 for Greece; Holtedahl and Joutz 2004 for Taiwan; Halicioglu 2007 for Turkey; Inglesi-Lotz 2011 for South Africa; Okajima and Okajima 2013 for Japan; AlBajjali and Shamayleh 2018 for Jordan). Other studies use panel data for a number of states or countries [Krishnamurthy and Kriström (2015) for OECD countries; Csereklyei (2020) for European Union]. The number of studies investigating residential demand for electricity with highly disaggregated household data is relatively limited (e.g. Nesbakken 1999; Bardazzi and Pazienza 2020) mainly due to non-availability of the necessary data.

An innovative idea for addressing this issue has been offered by Browning et al. (1985) who first pinpointed the key role of cohorts, thus introducing a new aspect into empirical analysis, the pseudo-panels approach. Pseudopanels are based on cohorts that are defined as groups of 
individuals with the same time-invariant characteristics. This analysis has been used for several research topics such as family consumption and labour supply (Browning et al. 1985), food consumption (Meng et al. 2014) and household demand for cars (Dargay and Vythoulkas 1999; Dargay 2002).

Regarding residential demand for electricity, the pseudo-panel approach is also new. Bernard et al. (2011) were the first who studied residential demand for electricity using pseudo-panel methodology by constructing 25 cohorts over the period 1989-2002 for the case of Canada. Silva et al. (2017, 2018) also investigated residential demand for electricity in Portugal using 350 cohorts over the period 1989-2010. More recently, Bardazzi and Pazienza (2020) built a pseudo-panel of Italian households over the period 1997-2016 and estimated cohort and age effects on long-run residential demand for electricity and natural gas. Finally, Belaïd et al. (2021) estimated the income elasticity of demand for electricity in the housing sector in France, using pseudo-panels taken from three independent microdata national housing surveys.

As shown in the empirical studies presented in Table 1, demand for electricity seems to be own-price and income inelastic. In particular, residential demand for electricity was found to be price inelastic in almost all studies, irrespective of the period of analysis, the geographic coverage of research or the methodological approach used (see, inter alia, Filippini and Pachauri 2004; Sun and Ouyang 2016; Silva et al. 2017; Bardazzi and Pazienza 2020). However, price elasticity can also be equal or greater to unity (e.g. Baker and Blundell 1991; Bernard et al. 2011; Ye et al. 2018; Díaz and Medlock 2021). Regarding the estimation of income elasticity, empirical studies show that demand for electricity is inelastic (e.g. Wiesmann et al. 2011; Khanna et al. 2016; Belaïd et al. 2021) implying that residential electricity is a normal good.

In addition, several factors have been incorporated into the empirical analysis as possible determinants of residential demand for electricity. These include socio-demographic factors such as population density, household age structure, urbanisation and dwelling characteristics such as house size, number of rooms, stock of appliances, etc. at macro- or micro-level (Cayla et al. 2011; Huang 2015; Jones et al. 2015; Esmaeilimoakher et al. 2016; Karatasou et al. 2018; Sakah et al. 2019); and climatic conditions such as temperature levels, heating and cooling degree days indices (Holtedahl and Joutz 2004; Kavousian et al. 2013; Khanna et al. 2016; Ye et al. 2018).

Finally, several empirical studies have investigated the possible correlation between residential electricity consumption and alternative energy sources. This is mainly done by including the cross-price of various energy sources such as liquefied petroleum gas, oil or natural gas in the demand function. These are considered to be substitutes for, or complementary to electricity (Beenstock et al. 1999; Alberini et al. 2011; Rosas-Flores et al. 2017; Ye et al. 2018; Díaz and Medlock 2021). Positive (negative) crossprice effects imply that other energy sources might be substitutes (complements), while weak or non-existent cross-price effects (Garcia-Cerrutti 2000) reflect limited switching uses. Possible explanations of this result can be the high financial cost of switching between energy carriers, the inadequate public knowledge about available substitutes or complements, or even their limited availability (Yu et al. 2014).

In the case of Greece, the empirical investigation of residential demand for electricity has received considerable attention, as shown in the studies in Table 2. Estimates of price elasticity of residential demand for electricity vary between -0.08 and -0.31 in the short run, and from -0.29 to -0.61 in the long run. The estimated income elasticity ranges in the short run from 0.19 to 1.33 and in the long run from 0.80 to 4.45 . It should be noted that most of the studies have employed time series approaches (such as OLS, VECM, ARDL, PRTS) to estimate the electricity price and income elasticities. Also, almost all the empirical studies have investigated residential demand for electricity for the period before the economic crisis. The only exceptions are the studies of Polemis and Dagoumas (2013) who marginally accounted the start of the crisis 2008-2011 in their research analysis and Kostakis' research (2020) which focused on microdata using a national household survey.

More specifically, most of the empirical studies agree that, both in the short and long run, price elasticity of residential demand for electricity is statistically significant but on the low side (Donatos and Mergos 1991; Hondroyiannis 2004; Rapanos and Polemis 2005). As for the short-run income elasticity, most studies confirm that residential electricity is a normal good with the exception of Christodoulakis and Kalyvitis (1997). On the contrary, the long-run income elasticity is estimated to be above unity, a result that differs from the cross-section empirical results (Table 1) and also from Dergiades and Tsoulfidis (2011) who found low-income elasticity. Zonzilos and Lolos (1996) found that income elasticity is insignificant and residential electricity consumption follows a random walk.

\section{The energy sector in Greece}

Over the decade 2008-2018, energy consumption in Greece decreased by $1 / 4$ as a result of the prolonged economic crisis and the drop in GDP. Thus, Greece's greenhouse gas emissions decreased significantly over that decade and the country achieved its renewable energy 
Table 1 Residential electricity demand studies using household data (excluding Greece)

\begin{tabular}{|c|c|c|c|c|c|}
\hline Study & Period & Country & Method & Income elasticity & Price elasticity \\
\hline Parti and Parti (1980) & 1975 & USA & $\mathrm{CDF}$ & 0.15 & -0.58 \\
\hline Dennerlein (1987) & 1977-1984 & Germany & DCCM & 0.42 & -0.38 \\
\hline Baker and Blundell (1991) & 1972-1988 & UK & AIDS & $0.17-0.28$ & -0.67 to -1.04 \\
\hline Branch (1993) & 1985 & USA & GLS & 0.23 & -0.20 \\
\hline Nesbakken (1999) & 1990-1992, 1994-1995 & Norway & DCCM & $0.01-0.28$ & -0.24 to -0.66 \\
\hline Metcalf and Hassett (1999) & $1984,1987,1990$ & USA & OLS,IV,FD & NA & -0.27 to -1.11 \\
\hline Halvorsen and Larsen (2001) & 1975-1994 & Norway & DCA & $0.06 / 0.13$ & $-0.43 /-0.42$ \\
\hline Filippini and Pachauri (2004) & 1993-1994 & India & OLS & $0.60-0.64$ & -0.29 to -0.51 \\
\hline Reiss and White (2005) & 1993-1997 & USA & OLS, GMM & NA & -0.29 to -0.49 \\
\hline Labandeira et al. (2006) & 1973-1995 & Spain & QUAIDS & $0.53-1.01$ & -0.44 to -0.80 \\
\hline Alberini et al. (2011) & 1997-2007 & USA & GLS, FE, GMM & $\begin{array}{l}0.01-0.02 \\
0.01 / 0.01\end{array}$ & $\begin{array}{l}-0.67 \text { to }-0.86 \\
-0.74 /-0.81\end{array}$ \\
\hline Bernard et al. (2011) & 1989-2002 & Canada & PP with FE & $0.08 / 0.20$ & $-0.51 /-1.32$ \\
\hline Ngui et al. (2011) & 2009 & Kenya & LA-AIDS & 0.85 & -0.63 to -0.88 \\
\hline Wiesmann et al. (2011) & 2005-2006 & Portugal & OLS & $0.05-0.12$ & NA \\
\hline Arthur et al. (2012) & $2002-2003$ & Mozambique & Deaton & 0.69 & -0.60 \\
\hline Zhou and Teng (2013) & 2007-2009 & China & OLS & $0.14-0.33$ & -0.35 to -0.50 \\
\hline Çetinkaya et al. (2015) & 2003-2012 & Turkey & Deaton, QR & $0.23 / 0.20$ & $-0.60 /-0.74$ \\
\hline Huang (2015) & 1981-2011 & Taiwan & QR & $0.37-0.55$ & NA \\
\hline Sun and Ouyang (2016) & 2013 & China & AIDS & 0.63 & -0.38 \\
\hline Khanna et al. (2016) & 2012 & China & OLS, QR & 0.15 & -0.51 \\
\hline Silva et al. (2017) & 1989-2011 & Portugal & $\mathrm{QR}$ & $0.28-0.33$ & -0.54 to -0.77 \\
\hline Schulte and Heindl (2017) & 1993-2008 & Germany & QAIDS & 0.40 & -0.43 \\
\hline Silva et al. (2018) & 1989-2011 & Portugal & FE, RE & $0.30-0.35$ & -0.67 to -0.90 \\
\hline Ye et al. (2018) & 2010-2011 & South Africa & $2 \mathrm{PM}$ & $0.13-0.43$ & -0.19 to -1.16 \\
\hline Athukorala et al. (2019) & 2011-2015 & Sri Lanka & OLS,FE,RE & $0.02-0.71$ & -0.002 to -0.14 \\
\hline Chindarkar and Goyal (2019) & $2005-12$ & India & OLS, FE & 0.59 & -0.31 to -0.46 \\
\hline Uhr et al. (2019) & 1988-1989, 2008-2013 & Brazil & QR & $0.20-0.32$ & -0.46 to -0.56 \\
\hline Balarama et al. (2020) & 2017 & Bangladesh & POLS,FE-(IV),RE,QR & NA & -0.57 \\
\hline Bardazzi and Pazienza (2020) & 1997-2016 & Italy & PP with FE & $0.15-0.46$ & -0.53 to -0.88 \\
\hline Belaïd et al. (2021) & 2000-2016 & France & PP with FE & 0.22 & NA \\
\hline Díaz and Medlock (2021) & 1992-2014 & Mexico & OLS, SUR, QUAIDS & Inelastic & -0.21 to -3.19 \\
\hline
\end{tabular}

$S R / L R$ Short-run and long-run elasticities, $N A$ non-available or not estimated, $C D F$ conditional demand functions, $D C C M$ discrete-continuous choice, $A I D S$ almost ideal demand system, $G L S$ generalised least squares, Model, $O L S$ ordinary least squares, $I V$ instrumental variables, $F D$ first difference, $D C A$ discrete continuous approach, $G M M$ general method of moments, $F E$ fixed effects, $P P$ pseudo-panels, $L A-A I D S$ linear approximate almost ideal demand system, $Q R$ quantile regression, $R E$ random effects, $2 P M$ two part model, $S U R$ seemingly unrelated regression, QAIDS quadratic almost ideal demand system

target for gross final energy consumption in 2020. In 2018, the residential sector absorbed $27 \%$ of total energy consumption, while transport absorbed $35 \%$, industry $19 \%$ and public services $12 \%$. Furthermore, the residential sector absorbed $36 \%$ of total electricity production, while another $36 \%$ was used by commercial and public services and $23 \%$ by industry (Alpha Bank 2020). Electricity generation has been dominated by lignite and oil (over $90 \%$ in the early 1990s) but the energy mix has gradually shifted away from lignite towards renewable energy sources and natural gas.
In 2018 , fossil fuels represented $68 \%$ of electricity generation (lignite $34 \%$, oil $10 \%$, natural gas $24 \%$ ) while the share of renewable energy sources and hydroelectric stations amounted to $21.5 \%$ and $10.5 \%$, respectively (European Commission 2020). Until the mid-2010s, the Public Power Corporation (PPC) had the monopoly in electricity generation from lignite and hydropower.

The composition of residential energy consumption by type of fuel in Greece and the EU-27 over the periods 2000-2008 and 2009-2018 is presented in Table 3 (Part 
Table 2 Residential electricity demand studies for Greece

\begin{tabular}{lllll}
\hline Study & Period & Method & Income elasticity & Price elasticity \\
\hline Donatos and Mergos (1991) & $1961-1986$ & OLS & $0.53 / 1.50$ & $-0.21 /-0.58$ \\
Zonzilos and Lolos (1996) & $1970-1993$ & ECM & Insignificant & NA \\
Christodoulakis and Kalyvitis (1997) & $1970-1990$ & OLS & $1.33 / 1.85$ & -0.25 \\
Hondroyiannis (2004) & $1986-1999$ & VECM & $0.20 / 1.56$ & $-0.14 /-0.41$ \\
Rapanos and Polemis (2005) & $1965-1999$ & PAM & $0.79 / 1.54$ & $-0.31 /-0.60$ \\
Dergiades and Tsoulfidis (2011) & $1964-2006$ & ARDL & $0.64 / 0.80$ & $-0.09 /-0.61$ \\
Lee and Chiu (2011) $^{\text {a }}$ & $1972-2004$ & PRTS & 0.47 & -0.23 \\
Polemis and Dagoumas (2013) & $1970-2011$ & EG & $0.19 / 4.45$ & $-0.08 /-0.29$ \\
Kostakis (2020) & 2017 & QR & $0.14-0.21$ & NA \\
\hline
\end{tabular}

$S R / L R$ Short-run and long-run elasticities, NA non-available or not estimated, $O L S$ ordinal least squares, $E C M$ error correction model, VECM vector error correction model, PAM partial adjustment model, ARDL autoregressive distributed lag, $P R T S$ panel smooth transition regression, $E G$ Engle and Granger, $Q R$ quantile regression

${ }^{a}$ Estimations refer to electricity demand and not to residential electricity demand

Table 3 Percentage composition of residential energy consumption in Greece and EU-27

\begin{tabular}{|c|c|c|c|c|c|c|c|c|c|c|}
\hline & \multicolumn{2}{|l|}{ Electricity } & \multicolumn{2}{|l|}{$\mathrm{Oil}^{\mathrm{a}}$} & \multicolumn{2}{|l|}{ Renewables $^{\mathrm{b}}$} & \multicolumn{2}{|l|}{ Natural gas ${ }^{\mathrm{c}}$} & \multicolumn{2}{|l|}{ Heat } \\
\hline & Greece $(\%)$ & $\mathrm{EU}(\%)$ & Greece $(\%)$ & $\mathrm{EU}(\%)$ & Greece $(\%)$ & $\mathrm{EU}(\%)$ & Greece $(\%)$ & $\mathrm{EU}(\%)$ & Greece $(\%)$ & $\mathrm{EU}(\%)$ \\
\hline \multicolumn{11}{|c|}{ Part A: Composition by type of fuel $(2000-2018)^{\mathrm{d}}$} \\
\hline 2000-2008 & 27.0 & 21.9 & 53.9 & 19.7 & 16.8 & 13.4 & 1.4 & 32.8 & 0.8 & 8. \\
\hline 2009-2018 & 35.1 & 23.9 & 34.1 & 13.4 & 22.9 & 18.6 & 6.7 & 31.9 & 1.1 & 8.6 \\
\hline \multicolumn{11}{|c|}{ Part B: Composition by category of end use $(2015-2018)^{\mathrm{e}}$} \\
\hline Total & $(100)$ & & $(100)$ & & $(100)$ & & $(100)$ & & $(100)$ & \\
\hline Space heating & 9.1 & 13.7 & 94.0 & 79.0 & 76.7 & 88.7 & 93.3 & 76.2 & 94.8 & 78.5 \\
\hline Space cooling & 10.1 & 1.4 & & & & & & & & \\
\hline Water heating & 16.1 & 12.2 & 3.5 & 13.7 & 22.2 & 9.1 & 6.3 & 18.0 & 7.0 & 21.5 \\
\hline Cooking & 12.8 & 12.1 & 2.4 & 6.6 & 1.1 & 1.8 & 0.4 & 5.8 & & \\
\hline Lighting and appliances & 51.9 & 57.2 & & & & & & & & \\
\hline
\end{tabular}

Source: Eurostat https://appsso.eurostat.ec.europa.eu/nui/show.do?dataset=nrg_d_hhq\&lang=en

${ }^{a}$ Diesel oil, LPG, kerosene

${ }^{\mathrm{b}}$ Solar, thermal, solid biofuels (excluding charcoal), biogases, ambient heat

${ }^{\mathrm{c}}$ Includes LNG

${ }^{\mathrm{d}}$ Solid fossil fuels amounting to 0.1 for Greece and 3.5 for EU are excluded

${ }^{\mathrm{d} C}$ Complete data series for Greece available from 2015

A). Greece followed the European trend, pursuing a new mix of cleaner fuel types. In particular, the share of consumption of oil and petroleum products in total residential energy consumption in Greece decreased by 20 percentage points between the periods 2000-2008 and 2009-2018. This drop is counterbalanced by an increase in alternative and more environmental-friendly energy uses as the contribution of natural gas, electricity and renewables-biofuels rose by approximately 5-7 percentage points each. Over the period 2009-2018, residential energy consumption is split between four types of fuel; electricity $(35.1 \%)$, oil and petroleum products $(34.1 \%)$, renewables and biofuels
(22.9\%) and natural gas (6.7\%). The use of solid fossil fuels and heat is negligible.

The pattern of residential energy consumption in the EU-27 is quite different (Table 3, Part A). The contribution of natural gas is very important, amounting to approximately $32 \%$ of total energy consumption, and it is followed by electricity use of about $24 \%$. It should be noted that the share of electricity in residential energy consumption in Greece is much greater, and amounts to $35 \%$. Also, between the periods 2000-2008 and 2009-2018 there has been a shift of about 5 percentage points in favour of renewables and biofuels, relative to oil and petroleum 
products. This structural change has been more limited compared to the developments in Greece over the same period (20 percentage points). However, in Greece, there is still high oil and petroleum dependency, with the consumption of these energy products three times that of the European average.

The composition of residential energy consumption by category of end use for the various fuel types (Table 3, Part B) shows that households in Greece use natural gas as well as oil almost exclusively for space heating (around 94\%). In the EU countries, fossil fuels are used to a lesser extent for space heating (around 78\%) and a higher use is observed for water heating and cooking. For electricity and renewables, the patterns of residential energy consumption do not differ significantly between the EU and Greece, with about half of the electricity use being directed to lighting and electrical appliances.

Over the last decade, the energy sector in Greece has been experiencing major reforms with the enhancement of competition, a restructuring state-owned companies and the liberalisation of the electricity and natural gas markets. These actions lead to more competitive and financially viable markets offering choices and low prices to consumers (IEA 2017; HAEE 2020). In order to introduce competition, the PPC was split into three separate companies for the production, the transmission and the distribution of energy (Law 4001/2011). Also, NOME (Nouvelle Organisation du Marché de l'Electricité) type auctions in electricity supply were introduced in 2016 to end the PPC's monopoly in electricity generation from hydropower and coal-fired stations. These actions ensure equal access to all electricity suppliers and are expected to reduce the retail and wholesale market share of the PPC to less than $50 \%$. As a result, the share of PPC in electricity production decreased from $97 \%$ in 2000 to $58 \%$ in 2018. NOME-type auctions were officially abolished in November 2019 and currently the operation of derivatives market will be providing a source of diversification. Finally, it should be noted that a regulation (Law 4643/2019) has been introduced to facilitate investments in renewable energy sources. The current legislative framework on the electricity market is in line with the European Directives.

Electricity prices have been fully liberalised since 2013. Household electricity prices increased during 2012-2014 but they de-escalated in later years (Fig. 1). Retail electricity prices in Greece followed a similar trend to those in other European countries and they rank below the average level of the EU (Eurostat). The course of oil prices, depicted in Fig. 1, is related to domestic and international developments.

Future energy prospects for Greece are set out in the Hellenic Republic (2019) which is the roadmap for the attainment of specific energy and climate objectives by
2030, ultimately leading to a climate-neutral economy by 2050. In line with the 2019 Plan, the Hellenic Republic (2020) for Greece (part of the "Next Generation EU" stimulus package) specifies the financing of particular actions in order to achieve the 2030 targets. About $40 \%$ of the budget of 32 billion euro will be allocated to green transition projects for the reduction of greenhouse gas emissions and the penetration of renewable energy sources into the energy system.

Specific actions include the substitution of lignite for natural gas in electricity generation plants on the mainland (Peloponnese, Northern Greece) to increase the efficiency of electricity production, as natural gas is the transition fuel to a low-carbon economy. The use of coal will have come to an end completely by 2028 and solar and wind parks will be built in areas close to presently existing coal plants.The fourteen coal-fired power plants currently operating in Greece will have phased-out by 2023. Complementary to the above actions is the replacement of costly oil-powered stations by renewable energy systems in the islands (Aegean Islands, Crete) that will help to keep the electricity price lower. Note that the Greek electricity regulatory system has the obligation to supply all consumers with the same electricity price. Since the oil-powered plants in the non-interconnected islands have high production costs compared to that in the mainland, the electricity suppliers in the islands are compensated through a levy imposed on all electricity consumers. However, the expansion of renewable electricity production requires the cable connection of non-interconnected islands with the electricity network of the mainland in order to strengthen and stabilise the grid, a project which is already underway. Also, in an effort to improve the efficient operation of the system, the installation of smart electricity meters is planned which will allow a two-way connection between suppliers and final consumers. Note that renewable energy is primarily used for residential purposes (73\%). In addition, the extended use of electric vehicles will be promoted, along with the development of charging stations, throughout the country. Finally, actions providing incentives for renovations and energy-saving measures in existing buildings are under way. These actions are expected to cover $10-15 \%$ of the building stock and absorb around $20 \%$ of total allocated funds of the Plan (32 billion euro), excluding the mobilisation of private and bank financing. The Plan also sets objectives for wide range digitisation of the economy and the promotion of the sustainable use of resources, climate resilience and environmental protection.

Over the decade of the 2020s, the residential energy sector in Greece is expected to decrease in size by $5 \%$ (mostly after 2025). Furthermore, according to the Hellenic Republic (2019), the residential sector will undergo major restructuring. A significant and continuous drop in the 
Fig. 1 Real residential electricity and heating oil prices (in Euro/kwh), 2009-2018. Sources: Eurostat and Statista. Authors' calculations.

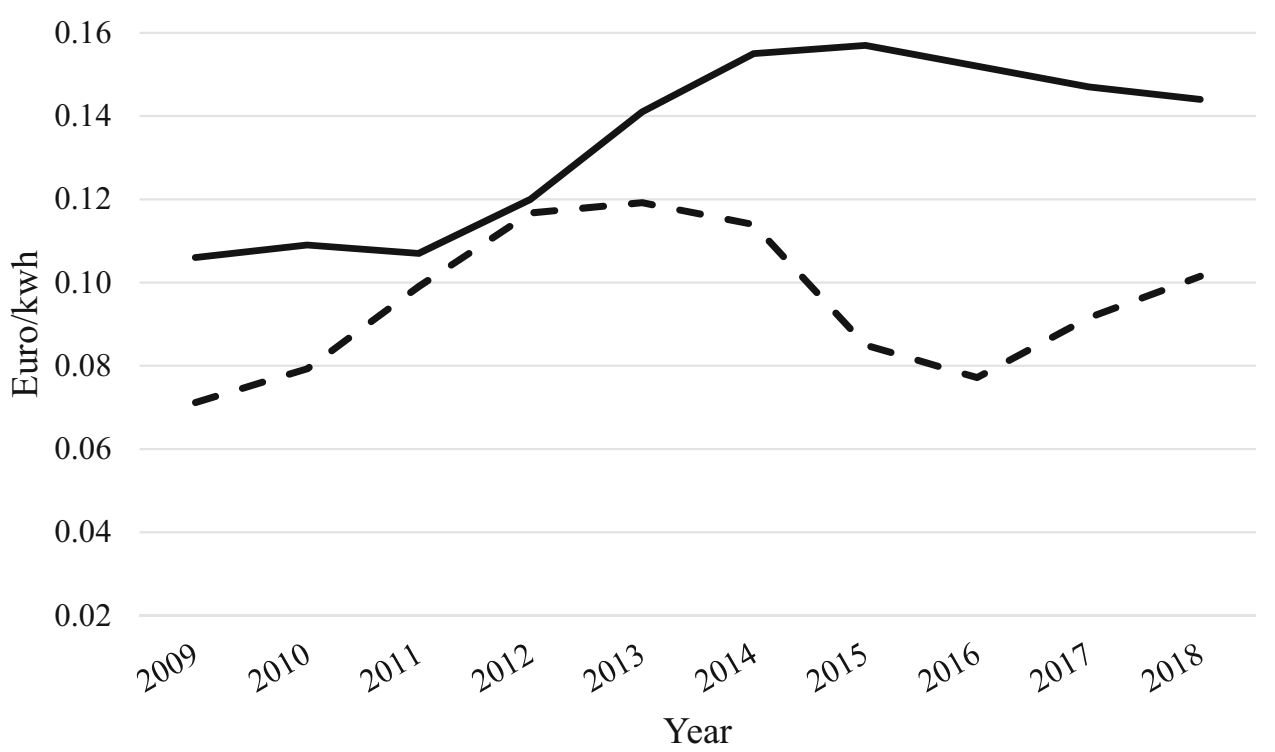

\section{- Electricity price - - Oil price}

share of heating oil in total residential energy consumption from $27 \%$ in 2020 to $10 \%$ is anticipated in 2030 . At the same time, an increase is expected in the use of natural gas, with its market share in total consumption increasing from $9 \%$ in 2020 to $15 \%$ in 2030 . Over the period 2020-2025, residential electricity consumption is expected to rise along with the country's economic recovery. After the mid2020s, electricity is expected to maintain its share in residential energy consumption to $39 \%$ (from $37 \%$ in 2020). Hence, the share of fossil fuels in residential energy use will drop from $36 \%$ in 2020 to $25 \%$ by 2030 , while the respective share of renewable energy sources is expected to increase from 27 to $36 \%$ in 2020 . Finally, it should be noted that renewable energy is primarily used for residential purposes $(73 \%)$.

\section{Methodology}

The pseudo-panel approach is used when real panel data are not available; however, this does not imply an estimation of lower precision (Garders et al. 2005). When only independent repeated cross-section data are available, a pseudo-panel can be constructed using subgroups of the cross-section data (cohorts). The cohort means are used as point observations in the pseudo-panel (Deaton 1985). Each cohort consists of a homogenous group of individuals who are assumed to sharing the same time-invariant characteristics from one cross-section survey to the next. These characteristics refer to the geographical location, the year of birth, the gender and so on of the head of the household (Verbeek 2008). However, since the means of cohort are based on sets of individuals, they are subject to possible measurement errors which can be minimised if the number of individuals in each cohort is sufficiently large. Generally, there is a trade-off between the number of subgroups and their size. A large cohort increases the heterogeneity of the pseudo-panel but decreases the average number of individuals per cohort leading to less precise estimates of the cohort means and vice versa.

Panel data are of utmost importance for the study of household energy behaviour but such data are not available in the case of Greece. Nevertheless, independent cross sections are published on an annual basis by the Hellenic Statistical Authority (ELSTAT). In our investigation, we adopt this alternative methodology by creating pseudopanels using subgroups of the available cross-section data. To the best of our knowledge, only Bernard et al. (2011) for Canada-, Silva et al. (2017)—for Portugal-and Belaiid et al. (2021)—for France-have employed the pseudo-panel approach in the estimation of residential electricity consumption. For the construction of model variables, as the available data consist of repeated cross sections of household surveys, we aggregated households into subgroups (cohorts) by taking the cross-sectional average of observed values for each cohort. In particular,

$\bar{k}_{c, t}=\frac{1}{n_{c, t}} \sum_{i=1}^{n} k_{i, t}$

where $\bar{k}_{c, t}$ is the average of all observed values $k_{i, t}$ in each cohort $c$ in period $t$ and $n_{c, t}$ is the size of the cohort.

Individual residential demand for electricity is derived from the theoretical traditional framework of the household production function (Becker 1965) indicating that 
residential electricity is not a final good, but it is used in the production of several other goods and services such as cooking, heating, lighting, etc. Thus, the empirical demand model that incorporates our research hypotheses and which can be used for all kinds of commodities, is represented by the following panel specification:

$$
\begin{gathered}
\ln \text { EleDemand }_{i, t}= \\
\quad \beta \ln \text { ElePrice }_{i, t}+\gamma \ln \text { Income }_{i, t}+\theta x_{i, t} \\
+\mu_{i}+\delta_{t}+\varepsilon_{i, t} \\
i=1,2, \ldots, N \text { and } t=1,2, \ldots, T
\end{gathered}
$$

where the dependent variable InEleDemand $_{i, t}$ of the demand for electricity model is defined as the natural logarithm of residential demand for electricity of household $i$ in the period $t ; \beta, \gamma$ and $\theta$ are the vectors of the associated coefficients. Unobserved individual effects $\mu_{i}$ and time effects $\delta_{t}$ enter the model additively (Bai 2009). Based on the traditional demand function, the main independent variables include lnElePrice ${ }_{i, t}$ which is the natural logarithm of the real price of household electricity consumption and InIncome $_{i, t}$ which is the natural logarithm of the annual real household disposable income. $x_{i, t}$ is a vector of other explanatory control variables and $\varepsilon_{i, t}$ represents the disturbance term.

The choice of the control variables included in the $x$ vector of Eq. (2) is based on previous empirical work on the subject (Labandeira et al. 2006; Sanquist et al. 2012; Kayalica et al. 2020). In particular, we account for possible substitutes or complements to household electricity consumption in line with recent research (Garcia-Cerrutti 2000; Rehdanz 2007; Zhang et al. 2018; Díaz and Medlock 2021). We examined the impact of the use of heating oil as an additional/alternative energy source on residential electricity consumption by including the natural logarithm of real price of heating oil (InOilPrice) in the model, on the grounds that the option of using electricity and/or oil is reflected in price differentials. Natural gas is also a possible alternative to heating oil. However, we did not investigate this option empirically since the determination of the wholesale price of natural gas is based on oil and petroleum products prices; oil indexed pricing of natural gas. Also, during the first half of our sample period, the residential use of natural gas was rather limited.

We also investigated the impact of socio-demographic factors on residential electricity consumption. In particular, we examined the effect of household size, that is, the average number of members within the household (InSize). Household size is expected to be positively related to electricity consumption, as larger households have higher electricity consumption (Bedir et al. 2013; Chindarkar and Goyal 2019). Variables reflecting climatic conditions that are based on weather measurements ('heating' and 'cooling degree days' indices) are also frequently considered determining factors of household energy consumption (Kavousian et al. 2013; Jovanović et al. 2015; Miller and Alberini 2016). Urbanisation may also affect residential electricity consumption (Chindarkar and Goyal 2019; Csereklyei 2020) and it is incorporated in our model by a dummy variable that takes the value of one if the household is located in an urban area and of zero otherwise. Urban areas are those with a population density of at least 500 inhabitants per $\mathrm{km}^{2}$.

Furthermore, education level may influence energy use due to different socialisation roles and lifestyles (Khanna et al. 2016; Frondel et al. 2019). It is captured by a dummy variable (University) taking the value of one if the head of a household holds a university degree and of zero otherwise. Income is also a key determinant of electricity consumption as it signifies a better quality of life. We included three income brackets in the model: low-income (up to $25 \%$ of income); medium-income (between 25 and 75\%); and high-income (above $75 \%$ of income) to account for possible heterogeneous price and income elasticities with respect to the economic status of households (Tiwari 2000; Bohlmann and Inglesi-Lotz 2021; Díaz and Medlock 2021). Empirically, we used two separate dummy variables (MedIncome) and (HighIncome), taking the value of one for medium and high-income quantiles, respectively, and of zero otherwise. ${ }^{1}$ The variables MedIncome, HighIncome, University and Urban were introduced in the model as interaction terms to investigate their possible heterogeneous behaviour regarding demand for electricity with respect to price and income changes. This is carried out by multiplying these variables with the real price of electricity and income, respectively.

Finally, a time effect was included in all models to control for economic growth that varies over time, electricity technological improvements and the possibility of a rebound effect (Okajima and Okajima 2013). This is an important model variable since the Greek economy underwent abrupt fluctuations as it was severely hit by the economic crisis over the period under study (2009-2018).

For the estimation of the model, we employed both static and dynamic approaches. These approaches address a number of possible statistical issues. For example, aggregation bias issues are avoided as we use disaggregated data and take into account household-level data in which households are price takers. Following the same procedure, we also investigated the possible heterogeneity of price and income resilience across different types of households with respect to certain variables discussed above. First, we

\footnotetext{
${ }^{1}$ Having a sample of 3 options for the income bracket dummies, 2 ( $\mathrm{n}$ 1) dummies should be included in the estimation. Low-income bracket is excluded being the baseline.
} 
estimated static fixed and random effects models but we preferred the fixed effects model on the basis of Hausman (1978) test. Subsequently, to ensure that the results are robust across different specifications, we estimated dynamic models. To address the issue that the lagged dependent variable of the equation is serially correlated with the error term, several estimators including Nickell (1981), Anderson and Hsiao (1982), Arellano and Bond (1991), Arellano and Bover (1995) and Blundell and Bond (1998) can be employed. We carried out the estimation using the generalised method of moments (Roodman 2009) that is consistent and asymptotically normal for large $n$ and small $t$ (Chamberlain 1984) as in our case. The one-way dynamic error component is specified as follows:

$$
\begin{aligned}
\ln _{\text {EleDemand }_{i, t}=} & \alpha_{i}+\beta_{1} \ln \text { EleDemand }_{i, t-1}+\beta_{2} \ln \text { ElePrice }_{i, t} \\
& +\beta_{3} \ln \text { Income }_{i, t}+\beta^{\prime} x_{i, t}+\gamma^{\prime} \omega_{i}+\varepsilon_{i, t}
\end{aligned}
$$

where $\alpha_{i}$ is the (unobserved) individual effect, $x_{i, t}$ is a vector of time-varying explanatory variables and $\omega_{i}$ is a vector of time-invariant variables. Equation (3) incorporates both the long-run equilibrium relation and the shortrun dynamics. However, we should mention that the Arellano-Bond estimator might suffer from weak instrument issue if the dependent variable has a unit root. To choose whether to utilise first-generation (e.g. Breitung 2000; Hadri 2000; Levin et al. 2002; Im et al. 2003) or second-generation (Pesaran 2007) panel unit root tests, we should test the hypothesis of cross-sectional independence (Pesaran 2004) in our data. If the assumption of crosssectional dependence holds, second-generation tests are appropriate and more reliable (O'Connell 1998). Another potential challenge is the reverse causality between price and electricity consumption that results in an upward bias in price elasticity of demand. Although there are a number of approaches instrumenting energy prices (e.g. lagged prices, aggregate prices, prices of similar products), it is often difficult to find the proper instruments (Taylor 1975; Reiss and White 2005). In our case, we used the lagged price of electricity as an instrument for the residential electricity price. We also use additional lags of the dependent variable as instruments for the lagged dependent variable since it is correlated with the error term.

Finally, we use quantile regressions to investigate whether the model coefficients vary for different levels of electricity consumption. Quantile regression specification allows flexibility in the estimated coefficients and enables us to obtain a range of conditional quantile functions while it remains robust to outliers. Thus, to account for possible heterogeneity among households, quantile regression analysis is employed as follows:

$Q_{d, i t}\left(y_{i t} \mid x_{i t}\right)=a(d)+x_{i t}^{D} a_{x}(d)+F_{e, i t}^{-1}(d)$ where $Q$ is the annual residential electricity consumption, $d$ is the quantile in the distribution of household electricity consumption and can take values between zero and unity; $x$ denotes the vector of independent variables; and $a_{x}(d)$ is the varying effect of the explanatory variables. $F_{e, i t}^{-1}(d)$ represents the inverse cumulative distribution function of $e_{i t}$.

Household data are derived from the annual Household Budget Surveys of the Hellenic Statistical Authority (ELSTAT 2020). The Surveys are based on the European Classification of Individual Consumption According to Purpose (COICOP). Survey responders are responsible for financial decisions at the household level and are requested to provide all required information. The data used in this study consist of annual data of all households over the period 2009-2018 and come from ten large-scale independent annual surveys. The data sample used consists of 360 cohorts with 36 subgroups for each of the annual cross sections.

Each pseudo-panel is defined by: six birth subgroups (those born in 1924 and subsequent 10-year intervals thereafter until 1993); two areas of residence (urban and rural); and three educational levels (lower, medium and higher). The criteria chosen for the construction of cohorts were the location of the household, and the level of education, as households located in the same area or having the same education level, is more likely to display similar behaviour with respect to energy consumption. Thus, each pseudo-panel contains 36 subgroups and for the ten-year period 2009-2018 a total of 360 cohorts are constructed. However, to ensure more robust estimations of the subgroup mean statistics, cohorts with less than 30 observations were excluded from the analysis (Meng et al. 2014). Also, based on Bodier (1999), we limit our sample to heads of households who are $25+$ as the very young are not well represented in the sample. The final number of cohorts used in the analysis is 330 .

Residential electricity consumption in physical terms (kwh) is calculated by dividing the total nominal expenditure on electricity by the euro/kwh price of electricity (Eurostat). For the calculation of consumption, we used the (medium) $d 2$ demand for electricity category prices that correspond to annual consumption between 2500-5000 kwh. In the empirical analysis, we used average and not marginal prices (Metcalf and Hassett 1999) on the grounds that households mainly respond to average prices which are also easily calculated (Shin 1985). The price of electricity is the average price of electricity of the residential sector obtained from Eurostat. Finally, nominal disposable income and prices of electricity and heating oil are deflated by the national harmonised commodity price index of the 
2015 base year. The descriptive statistics of the variables used in the empirical analysis are summarised in Table 4.

\section{Results and discussion}

Tables 5 and 6 report the results of the estimated residential demand for electricity (static and dynamic) models that address our research hypotheses. We estimated versions of the model by controlling for different variables. Accordingly, Model 1 includes the real price of residential electricity, real disposable income, the real price of heating oil, household size and a time effect. Models 2 and 3 are further extended to account for possible heterogeneity of price and income elasticities using interaction terms with respect to income status, education level and urbanisation.
Besides the static models, we also estimated dynamic models of residential demand for electricity to investigate if there is differentiation between the short-run and longrun elasticities of the demand function. Before embarking on the dynamic analysis, we address the issue of common correlation bias in the panel data, as it is important to come up with unbiased estimations. This is carried out, first by applying the Pesaran (2004) cross-dependence test, where the null hypothesis of cross-sectional independence in our data is strongly rejected by the statistical tests shown in Table 5. This result indicates that we should apply the second-generation unit root approach to identify the order of integration of the dependent variable. In doing so, we employ the cross-sectional augmented panel unit root test developed by Pesaran (2007). Our findings confirm that the dependent variable of the demand function does not have a unit root (Okajima and Okajima 2013). This indicates that
Table 4 Definition of variables and descriptive statistics

\begin{tabular}{ll}
\hline Part A: Cohort variables & \\
\hline Variable & Value \\
Birth year & 1. $1924-1933$ \\
& 2. $1934-1943$ \\
& . \\
& 6. $1984-1993$ \\
Region of living & 1. Urban (at least 500 inhabitants $/ \mathrm{km}^{2}$ ) \\
& 2. Rural (between 0 and 499 inhabitants $/ \mathrm{km}^{2}$ ) \\
Educational level & 1. Lower (primary and lower secondary education) \\
& 2. Median (upper and post-secondary education) \\
& 3. Higher (higher education first and second stage)
\end{tabular}

Part B: Electricity consumption $(\mathrm{kWh})$

\begin{tabular}{lllll}
\hline Variable & Mean & SD & Min & Max \\
\hline All cohorts & 4264.14 & 760.89 & 2348.67 & 7178.36 \\
Age cohort 1 (1924-1933) & 3724.63 & 597.57 & 2510.29 & 5428.17 \\
Age cohort 2 (1934-1943) & 4446.25 & 555.82 & 3493.98 & 5759.55 \\
Age cohort 3 & 4692.79 & 680.19 & 3521.66 & 6193.82 \\
Age cohort 4 & 4448.87 & 625.49 & 3408.77 & 6115.23 \\
Age cohort 5 & 4367.13 & 801.56 & 3075.98 & 7178.36 \\
Age cohort 6 (1984-1993) & 3865.15 & 787.21 & 2348.67 & 6801.31 \\
Urban area cohort & 4264.68 & 779.34 & 2794.81 & 7178.36 \\
Rural area cohort & 4263.59 & 744.14 & 2348.67 & 6264.00 \\
Lower educational level cohort & 3920.54 & 645.58 & 2348.67 & 5491.71 \\
Medium educational level cohort & 4255.66 & 637.45 & 2510.29 & 6158.58 \\
Higher educational level cohort & 4616.21 & 824.22 & 2827.68 & 7178.36 \\
Real electricity price (Euro/kWh) & 0.134 & 0.020 & 0.106 & 0.157 \\
Real oil price (Euro/litre) & 1.005 & 0.173 & 0.749 & 1.254 \\
Real household total expenditure (Euro) & 23,970 & 8344 & 10,794 & 61,848 \\
Household size (number) & 2.53 & 0.59 & 1.50 & 3.79 \\
\hline
\end{tabular}

Source: Hellenic Statistical Authority (2020) 
Table 5 Residential demand for electricity, 2009-2018 (dependent variable lnEleDemand)

\begin{tabular}{|c|c|c|c|c|c|c|}
\hline Variables & Model 1 & Model 2 & Model 3 & Model 4 & Model 5 & Model 6 \\
\hline Constant & $\begin{array}{l}-112.57 * * * \\
(7.791)\end{array}$ & $\begin{array}{l}112.45^{* * *} \\
(6.575)\end{array}$ & $\begin{array}{l}-113.59 * * * \\
(7.299)\end{array}$ & - & - & - \\
\hline Lagged dependent & - & - & - & $\begin{array}{l}0.420 * * * \\
(0.079)\end{array}$ & $\begin{array}{l}0.365 * * * \\
(0.079)\end{array}$ & $\begin{array}{l}0.379 * * * \\
(0.082)\end{array}$ \\
\hline InIncome & $\begin{array}{l}0.357 * * * \\
(0.069)\end{array}$ & $\begin{array}{l}0.332 * * * \\
(0.056)\end{array}$ & $\begin{array}{l}0.290 * * * \\
(0.070)\end{array}$ & $\begin{array}{l}0.194 * * * \\
(0.063)\end{array}$ & $\begin{array}{l}0.239 * * * \\
(0.080)\end{array}$ & $\begin{array}{l}0.307 * * * \\
(0.083)\end{array}$ \\
\hline InElePrice & $\begin{array}{l}-0.822 * * * \\
(0.044)\end{array}$ & $\begin{array}{l}-0.757 * * * \\
(0.047)\end{array}$ & $\begin{array}{l}-0.827 * * * \\
(0.042)\end{array}$ & $\begin{array}{l}-0.454 * * * \\
(0.085)\end{array}$ & $\begin{array}{l}-0.489 * * * \\
(0.079)\end{array}$ & $\begin{array}{l}-0.492 * * * \\
(0.079)\end{array}$ \\
\hline InOilPrice & $\begin{array}{l}-0.173 * * * \\
(0.026)\end{array}$ & $\begin{array}{l}-0.174 * * * \\
(0.023)\end{array}$ & $\begin{array}{l}-0.172 * * * \\
(0.029)\end{array}$ & $\begin{array}{l}-0.206^{* * *} \\
(0.030)\end{array}$ & $\begin{array}{l}-0.197^{* * *} \\
(0027)\end{array}$ & $\begin{array}{l}-0.192 * * * \\
(0.028)\end{array}$ \\
\hline lnSize & $\begin{array}{l}0.444 * * * \\
(0.148)\end{array}$ & $\begin{array}{l}0.430 * * * \\
(0.127)\end{array}$ & $\begin{array}{l}0.410 * * * \\
(0.132)\end{array}$ & $\begin{array}{l}0.303 * * * \\
(0.122)\end{array}$ & $\begin{array}{l}0.318 * * * \\
(0.116)\end{array}$ & $\begin{array}{l}0.310 * * \\
(0.117)\end{array}$ \\
\hline $\begin{array}{c}\text { MedIncome } \times \\
\text { lnElePrice }\end{array}$ & - & $\begin{array}{l}0.011 * * \\
(0.005)\end{array}$ & - & - & $\begin{array}{l}0.007 \\
(0.008)\end{array}$ & - \\
\hline $\begin{array}{l}\text { HighIncome } \times \\
\text { InElePrice }\end{array}$ & - & $\begin{array}{l}-0.012 * \\
(0.007)\end{array}$ & - & - & $\begin{array}{l}-0.008 \\
(0.013)\end{array}$ & - \\
\hline University $\times$ lnElePrice & - & $\begin{array}{l}-0.254 * * * \\
(0.060)\end{array}$ & - & - & $\begin{array}{l}-0.147 * * \\
(0.064)\end{array}$ & - \\
\hline MedIncome $\times$ lnIncome & - & - & $\begin{array}{l}-0.002 * * * \\
(0.001)\end{array}$ & - & - & $\begin{array}{l}-0.002 \\
(0.002)\end{array}$ \\
\hline HighIncome $\times$ lnIncome & - & - & $\begin{array}{l}0.002 * \\
(0.001)\end{array}$ & - & - & $\begin{array}{l}0.003 \\
(0.003)\end{array}$ \\
\hline University $\times$ InIncome & - & - & $\begin{array}{l}0.168 * * * \\
(0.049)\end{array}$ & - & - & $\begin{array}{l}0.068 * * \\
(0.025)\end{array}$ \\
\hline $\begin{array}{c}\text { Urbanisation } \times \\
\text { InElecPrice }\end{array}$ & - & $\begin{array}{l}0.020 \\
(0.056)\end{array}$ & - & - & $\begin{array}{l}0.061 \\
(0.052)\end{array}$ & - \\
\hline $\begin{array}{l}\text { Urbanisation } \times \\
\text { lnIncome }\end{array}$ & - & - & $\begin{array}{l}-0.020 \\
(0.040)\end{array}$ & - & - & $\begin{array}{l}-0.133 * \\
(0.073)\end{array}$ \\
\hline Time & $\begin{array}{l}0.057 * * * \\
(0.004)\end{array}$ & $\begin{array}{l}0.057 * * * \\
(0.003)\end{array}$ & $\begin{array}{l}0.057 * * * \\
(0.003)\end{array}$ & $\begin{array}{l}0.039 * * * \\
(0.004)\end{array}$ & $\begin{array}{l}0.042 * * * \\
(0.004)\end{array}$ & $\begin{array}{l}0.042 * * * \\
(0.004)\end{array}$ \\
\hline R-squared & 0.72 & 0.76 & 0.75 & - & - & - \\
\hline Price $95 \%^{\mathrm{a}}$ & $-0.911 /-0.733$ & $-0.854 /-0.661$ & $-0.912 /-0.742$ & $-0.626 /-0.281$ & $-0.647 /-0.331$ & $-0.652 /-0.331$ \\
\hline Income $95 \%^{\mathrm{a}}$ & $0.216 / 0.497$ & $0.218 / 0.445$ & $0.148 / 0.433$ & $0.066 / 0.322$ & $0.075 / 0.403$ & $0.138 / 0.475$ \\
\hline AR (1) & - & - & - & 0.000 & 0.000 & 0.000 \\
\hline AR (2) & - & - & - & 0.098 & 0.120 & 0.175 \\
\hline Sargan test & - & - & - & 0.151 & 0.111 & 0.066 \\
\hline Hansen test & - & - & - & 0.131 & 0.097 & 0.079 \\
\hline
\end{tabular}

Models 1-3 are fixed effects; Model 4-6 are one step FD-GMM; CD-test: 44.74 ( $p$-value $=0.000$ ); CIPS-test (with constant) $-3.117 * * *$; CIPStest (with constant and trend) $-3.638 * * *$; Observations 330; Number of groups 36

${ }^{a}$ Confidence intervals; robust standard errors in parentheses

$* p<0.1$

$* * p<0.05$

$* * * p<0.01$

we can safely proceed with the first difference generalised method of moments. To ensure the GMM estimation consistency, we employ additional diagnostic tests. The
Arellano and Bond (1991) test is used to confirm that the first difference error term is without second-order serial correlation. Furthermore, to address endogeneity issue, we 


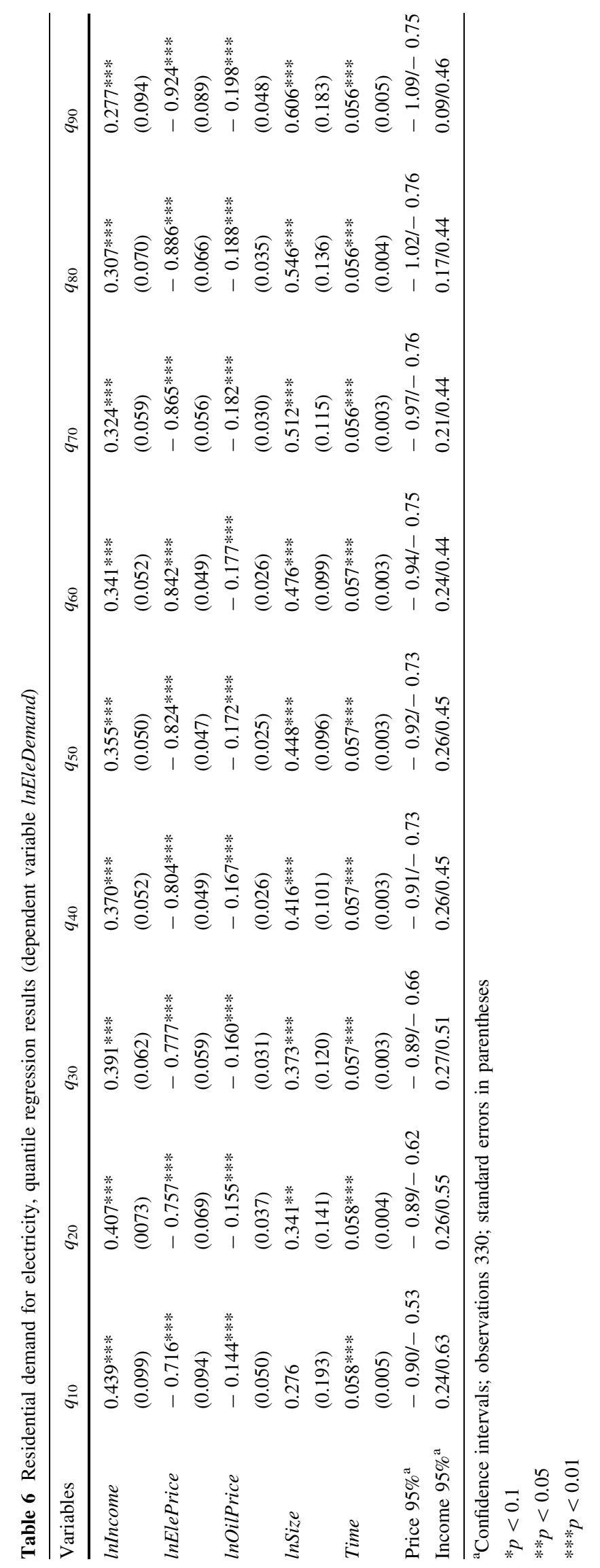


used lagged electricity price and electricity consumption as instruments into our analysis. Then, the Sargan (1958) and Hansen (1982) tests are utilised to confirm the validity of the instruments. Lastly, to avoid sample biases caused by overfitting, we ensure that the number of instruments is smaller than the number of groups in the estimated specifications.

The results reported in Table 5 indicate that the elasticity of the real price of electricity has the expected negative sign and is statistically significant in all specifications, validating our first research hypothesis. In the static Models 1-3, the estimated own-price elasticity of demand for electricity ranges from -0.76 to -0.83 (average across models is -0.80 ) indicating that the use of electricity is highly respondent to price changes. Wald tests and confidence intervals at $95 \%$ confirm that the value of price elasticity is less than unity in all specifications. These values of price elasticity are in line with several previous empirical studies that have used aggregated (Bölük and Koç 2010; Lim et al. 2014; Campbell 2018) and disaggregated data (Bernard et al. 2011; Ngui et al. 2011; Bardazzi and Pazienza 2020). Our findings show that Greek households do respond to price changes with respect to demand for electricity, as a $10 \%$ increase in the real price of electricity results in a decrease in the residential quantity demand for electricity by $8 \%$ on average.

The results of the dynamic specification are shown in Table 5 (Models 4-6) and examine whether there is a differentiation between the short-run and long-run elasticities of the demand function. The results reveal that the coefficient of the long-run adjustment of demand for electricity ranges from 0.37 to 0.42 (average across models is 0.39 ). The short-term own-price elasticity is negative and statistically significant with an average value of -0.48 (close to Halvorsen and Larsen 2001; Labandeira et al. 2006; Bernard et al. 2011; Zhou and Teng 2013; Schulte and Heindl 2017; Uhr et al. 2019; Balarama et al. 2020) and is fairly stable across the models. Wald tests and confidence intervals at $95 \%$ highly reject the hypothesis that the absolute value of the price elasticity is equal to or higher than unity, confirming that the demand for electricity is price inelastic. The estimated long-run price elasticity has an average value of -0.78 (Bohi and Zimmerman 1984; Alberini et al. 2011; Çetinkaya et al. 2015) which is almost the same as the average medium/long-run estimated elasticities of the static models. The long-run elasticity is obtained by $\frac{\beta}{1-\rho}$ where $\beta$ is the short-run estimated coefficient and $\rho$ is the coefficient of the lagged dependent variable.

Our empirical findings indicate that the income elasticity of residential demand for electricity is positive and statistically significant in all specifications, confirming our second research hypothesis. In static Models 1-3, income elasticity ranges from 0.29 to 0.36 (average across models 0.33 ). The values of the short-run income elasticity of the dynamic specifications are also positive and statistically significant ranging from 0.19 to 0.31 (average 0.25 ), which are very close to a number of previous studies (Branch 1993; Nesbakken 1999; Hondroyiannis 2004; Polemis and Dagoumas 2013; Çetinkaya et al. 2015; Silva et al. 2017; Uhr et al. 2019; Kostakis 2020; Belaïd et al. 2021). All tests indicate that demand for electricity is also income inelastic, confirming that electricity is a normal good. The estimated average long-run elasticity is 0.40 (from 0.33 to 0.49) which is also close to the value reported in many empirical studies (Dennerlein 1987; Lee and Chiu 2011; Huang 2015; Schulte and Heindl 2017; Ye et al. 2018). Thus, a $10 \%$ increase in household income gives rise approximately to a $4 \%$ increase in residential electricity consumption. Our result can be attributed to the increasing trend of residential electricity consumption along with the rise in income, or to the fact that wealthier households may tend to move into larger dwellings with higher electricity consumption requirements (Nesbakken 1999). As for future prospects, an anticipated rise in household incomes in the post-Covid-19 period is expected to boost residential demand for electricity.

Regarding the control variables, our empirical results confirm our third research hypothesis, that there is a complementary effect between electricity and heating oil (Halvorsen and Larsen 2001), as the real price of heating oil has a negative and statistically significant impact (crossprice elasticity with respect to heating oil) on the determination of residential demand for electricity of approximately -0.19 . We believe that electricity and heating oil in Greece are in fact complementary goods since oil is used almost exclusively for space heating (94\%) while electricity is consumed for all other household uses (cooking, water heating, lighting and space cooling) to an extent of $91 \%$. We believe that in the future, the use of electricity will increase along with the expected drop in prices since the Mediterranean climatic conditions of the country require expansion of space cooling and rather limited heating needs. In addition to its environmental superiority, the residential use of electricity has the advantage of a relatively low installation cost, as it can be used both for space heating and cooling and certain types of electrical equipment can be used both for heating and cooling purposes.

If we look at the effects of the socio-demographic variables, our findings validate our fourth research hypothesis. In particular, that the size of the household (lnSize) has, as expected, a positive and statistically significant impact on residential electricity consumption (Cayla et al. 2011; Bedir et al. 2013; Khanna et al. 2016; 
Frondel et al. 2019). The positive association between household size and electricity use indicates that when there are more people within a household several electric appliances might be used more frequently. Also, there is a higher likelihood of finding that when there are more members in a household, they tend to spend more time at home. And finally, it is common that larger households live in larger dwellings with higher electricity needs.

We then investigate whether price and income elasticities vary with respect to certain variables via several interaction terms (Reiss and White 2005; Silva et al. 2017; Chindarkar and Goyal 2019). The results in Model 2 show that medium-income (MedIncome) and high-income level (HighIncome) households have in magnitude a statistically significant but very marginal impact on price elasticity compared to low-income households; while their impact on income elasticity (Model 3) is similar in significance and magnitude. On the other hand, households with a higher educational level (University) have a significant impact on price and income elasticity that increase the value of the respective elasticities, since the more educated people become, the more sensitive they are to environmental issues (Torgler and Garcia-Valinas 2007; Frondel et al. 2019). Regarding the results of the dynamic specifications (Models 5-6), the education variable retains its impact but the income variables lose their statistical significance.

Also, looking at Urbanisation, households located in urban areas do not have statistically significantly different electricity consumption elasticities compared to those in rural areas. We also estimated separate demand functions for households located in urban and in rural areas but the income elasticities were very close confirming the results of Table 5. Since electricity is mainly used for lighting, cooking and space cooling across the country, a differentiation of the residential electricity price effect with respect to urbanisation is not expected. In particular, it has a negative marginal effect on income elasticity indicating that the effect of income on residential electricity consumption might be lower for households in urban areas.

Moreover, we found that a rebound effect is present in all specifications (Sorrell and Dimitropoulos 2008; Okajima and Okajima 2013; Labidi and Abdessalem 2018) denoting that technological progress might gradually lead to higher electricity consumption as people use more electric and IT devices. We also investigated the impact of climatic conditions on residential electricity consumption using 'heating degree days' and 'cooling degree days' indices but the results were insignificant without improving the model (Halvorsen and Larsen 2001) and therefore, these variables were dropped from the specification. ${ }^{2}$ This result also confirms previous findings that the economic

$\overline{2}$ The results are available from the authors upon request. crisis in Greece, which coincided with our sample period (2009-2018), forced households to save on energy costs, thus violating the relationship between residential energy requirements and climatic conditions (Hellenic Republic 2019, p. 293).

Next, we investigated whether model elasticities vary with different levels of electricity consumption (Çetinkaya et al. 2015; Huang 2015; Khanna et al. 2016; Uhr et al. 2019; Balarama et al. 2020; Kostakis 2020) by estimating quantile regression models for electricity deciles (from $q=10 \%, q=20 \%, \ldots$, to $q=90 \%$ ). As shown in the model results of Table 6 , all the estimated coefficients are statistically significant with the expected positive/negative signs. In addition, the average values of the estimated elasticities confirm the results of the respective models presented in Table 5.

Quantile regression results show that income elasticities gradually decrease as the quantity of electricity used increases, signifying that high electricity-consuming households are less sensitive to income changes than low electricity-consuming ones. More specifically, a $10 \%$ increase in income for a low electricity consumer $\left(q_{10}=10 \%\right)$ will lead approximately to a $4.4 \%$ increase in electricity consumption, whereas the same income rise for a high electricity consumer $\left(q_{90}=90 \%\right)$ will lead approximately to a $2.8 \%$ increase in electricity consumption. Our results also indicate that the absolute value of price elasticities gradually increases as we move towards the upper tail of the electricity consumption distribution (Nesbakken 1999; Schulte and Heindl 2017). Therefore, high electricity consumers are more sensitive to price changes compared to those with lower consumption. Price elasticities at high $\left(q_{90}=90 \%\right)$ and low $\left(q_{10}=10 \%\right)$ electricity consumption levels amount to -0.92 and -0.72 , respectively. Our results confirm our fifth research hypothesis that income and price responsiveness is related to the level of electricity consumption.

It is also interesting that the absolute value of crossprice elasticity of heating oil gradually increases along with the increase in electricity consumption level, indicating that high electricity consumers are more sensitive to oil price changes than those with lower electricity consumption. The oil price elasticity for high and low electricity consumers is -0.20 and -0.15 , respectively. Finally, the empirical results show that the positive effect of household size on demand for electricity increases with the rise in electricity consumption (Huang 2015; Frondel et al. 2019). The elasticity of household size for high electricity consumers is twice that of low consumers. 


\section{Conclusions}

This paper provides empirical evidence, for the first time, on the behaviour of residential electricity consumption in Greece using a pseudo-panel approach. Our empirical investigation relies on the use of pseudo-panels constructed from disaggregated household data of independent annual Household Budget Surveys conducted over the period 2009-2018 by ELSTAT. The econometric investigation is carried out using static and dynamic models and a quantile regression model. Our paper closes the gap between pseudo-panel and microeconomic panel data approaches in the case of residential demand for electricity. The study is a useful input for the design and assessment of energy policy in Greece as well as in other countries or sectors sharing similar characteristics.

The results show that residential demand for electricity is price and income inelastic both in the short and the long run. The value of the own-price elasticity in the static models and the long-run price elasticity of the dynamic models is approximately -0.80 on average across models, while the average short-run price elasticity is -0.48 . Also, the values of the respective income elasticities are about 0.35 and 0.25 . Electricity and heating oil seem to be complementary energy sources, as oil is used for space heating and electricity for all other uses. Household size is also an important determinant of residential demand for electricity, while urbanisation is insignificant. The level of education is a key factor in the determination of household electricity consumption but income status has a marginal effect. Regarding the quantile regression model, our results show that as the level of electricity use rises, demand for electricity becomes less income responsive and more price responsive. Finally, increasing responsiveness is detected for the oil price and the household size parameters with an increase in energy use.

Our empirical results provide useful insights for future energy developments and also have important policy implications. In particular, the low value of income elasticity of demand $(0.35)$ shows that the expected future rise in incomes in Greece after the prolonged economic and Covid-19 recessions will only increase residential electricity consumption marginally. Also, the expected drop in electricity prices, due to the structural changes that are planned, will increase electricity consumption, but not to a great extent as demand for electricity is price inelastic $(-0.80)$.

In light of our quantile regression results, the benefits of the specific energy-saving programme which provides incentives for "renovation and energy saving in buildings", appear to be greater than perceived in terms of energy saving. Consider a household that enters the programme and moves from a high to a low electricity consumption bracket. This household-now positioned in the low electricity bracket-will face lower price elasticity $(-0.7$ instead of -0.9 ) and marginally higher income elasticity (0.4 instead of 0.3). Thus, if there is a drop in electricity prices, this household will increase electricity consumption by less than if it were in the initial high electricity consumption bracket. Furthermore, if there is a rise in income, this household will increase electricity consumption, but only marginally compared to its initial high electricity consumption. All in all, the implementation of the programme will bring about a wide range of benefits highlighted by our empirical results.

Furthermore, the introduction of a low-carbon tax on oil as a disincentive for the use of fossil fuels will compress the consumption of heating oil and also the consumption of electricity since both fuels are complements. The reduction of the level of electricity consumption will activate the mechanism described above that will lead to further electricity saving and eventually to more efficient energy use. Similar effects will take place in the case of a possible increase in oil prices.

The empirical results in this study must be interpreted with caution since they rely on existing datasets that are limited in many respects. Annual datasets do not capture short-term fluctuations that may be important for household behaviour. Also, datasets should contain more information on various household aspects such as financial parameters, lifestyle and dwelling characteristics. The inclusion of regional variables in the dataset will allow for the empirical investigation to capture the country's specificities more thoroughly. Finally, pseudo-panels are not based on highly disaggregated data which might lead to measurement errors.

Acknowledgements The authors wish to gratefully acknowledge George Hondroyiannis for his helpful discussions and suggestions. Emi Stamatopoulou, Helga Stefansson and four anonymous referees are also acknowledged for constructive comments and suggestions that improved the quality of the paper. The views expressed are those of the authors and not those of their respective institutions.

Funding This research has not received any grant from funding agencies in the public, private, or non-profit sectors.

\section{Declarations}

Conflict of interest The authors declare that they have no conflict of interest.

\section{References}

Al-Bajjali SK, Shamayleh AY (2018) Estimating the determinants of electricity consumption in Jordan. Energy 147:1311-1320. https://doi.org/10.1016/j.energy.2018.01.010 
Alberini A, Gans W, Velez-Lopez D (2011) Residential consumption of gas and electricity in the US: the role of prices and income. Energy Econ 33(5):870-881. https://doi.org/10.1016/j.eneco. 2011.01.015

Alpha Bank (2020) Energy, Greece Sectors in focus. https://www. alpha.gr/-/media/alphagr/files/group/agores/sectors-in-focus/sec tors_in_focus_energy_april2020.pdf

Anderson TW, Hsiao C (1982) Formulation and estimation of dynamic models using panel data. J Econom 18(1):47-82. https://doi.org/10.1016/0304-4076(82)90095-1

Arthur MDSR, Bond CA, Willson B (2012) Estimation of elasticities for domestic energy demand in Mozambique. Energy Econ 34(2):398-409. https://doi.org/10.1016/j.eneco.2011.08.006

Athukorala W, Wilson C, Managi S, Karunarathna M (2019) Household demand for electricity: the role of market distortions and prices in competition policy. Energy Policy 134:110-932. https://doi.org/10.1016/j.enpol.2019.110932

Arellano M, Bond S (1991) Some tests of specification for panel data: Monte Carlo evidence and an application to employment equations. Rev Econ Stud 58(2):277-297. https://doi.org/10. 2307/2297968

Arellano M, Bover O (1995) Another look at the instrumental variable estimation of error-components models. J Econom 68(1):29-51. https://doi.org/10.1016/0304-4076(94)01642-D

Bai J (2009) Panel data models with interactive fixed effects. Econometrica 77(4):1229-1279. https://doi.org/10.3982/ ecta6135

Baker P, Blundell R (1991) The microeconometric approach to modelling energy demand: some results for UK households. Oxford Rev Econ Policy 7:54-76. https://doi.org/10.1093/oxrep/ 7.2 .54

Baker P, Blundell R, Micklewright J (1989) Modelling household energy expenditures using micro-data. Econ J 99(397):720-738. https://doi.org/10.1093/oxrep/7.2.54

Balarama H, Islam A, Kim JS, Wang LC (2020) Price elasticities of residential electricity demand: estimates from household panel data in Bangladesh. Energy Econ 92:104937. https://doi.org/10. 1016/j.eneco.2020.104937

Bardazzi R, Pazienza MG (2020) When I was your age: generational effects on long-run residential energy consumption in Italy. Energy Res Soc Sci 70:101611. https://doi.org/10.1016/j.erss. 2020.101611

Becker G (1965) A theory of the allocation of time. Econ J 75(299):493-517. https://doi.org/10.2307/2228949

Bedir M, Hasselaar E, Itard L (2013) Determinants of electricity consumption in Dutch dwellings. Energy Build 58:194-207. https://doi.org/10.1016/j.enbuild.2012.10.016

Beenstock M, Goldin E, Nabot D (1999) The demand for electricity in Israel. Energy Econ 21(2):168-183. https://doi.org/10.1016/ s0140-9883(98)00005-x

Belaïd F, Rault C, Massié C (2021) A life-cycle analysis of French household electricity demand CESifo working paper no 8814 . https://ssrn.com/abstract=3767686

Bernard JT, Bolduc D, Yameogo ND (2011) A pseudo-panel data model of household electricity demand. Resour Energy Econ 33:315-325. https://doi.org/10.1016/j.reseneeco.2010.07.002

Blundell R, Bond S (1998) Initial conditions and moment restrictions in dynamic panel data models. J Econom 87(1):115-143. https:// doi.org/10.1016/s0304-4076(98)00009-8

Bodier M (1999) Les effets d'âge et de génération sur le niveau et la structure de la consommation. Économie Et Statistique 324(1):163-180. https://doi.org/10.3406/estat.1999.6217

Bohi DR, Zimmerman MB (1984) An update on econometric studies of energy demand behavior. Ann Rev Energy 9(1):105-154. https://doi.org/10.1146/annurev.eg.09.110184.000541
Bohlmann JA, Inglesi-Lotz R (2021) Examining the determinants of electricity demand by South African households per income level. Energy Policy 148:111901. https://doi.org/10.1016/j. enpol.2020.111901

Bölük G, Koç AA (2010) Electricity demand of manufacturing sector in Turkey: a translog cost approach. Energy Econ 32:609-615. https://doi.org/10.1016/j.eneco.2010.01.007

Branch ER (1993) Short run income elasticity of demand for residential electricity using consumer expenditure survey data. Energy J 14:111-121. https://doi.org/10.5547/issn0195-6574-ejvol14-no4-7

Breitung J (2000) The local power of some unit root tests for panel data. In: Baltagi BH (ed) Advances in econometrics, volume 15: non-stationary panels, panel cointegration, and dynamic panels. JAY Press, Amsterdam, pp 161-178. https://doi.org/10.1016/ s0731-9053(00)15006-6

Browning M, Deaton A, Irish M (1985) A profitable approach to labor supply and commodity demands over the life-cycle. Econometrica. https://doi.org/10.2307/1911653

Campbell A (2018) Price and income elasticities of electricity demand: evidence from Jamaica. Energy Econ 69:19-32. https:// doi.org/10.1016/j.eneco.2017.10.040

Cayla JM, Maizi N, Marchand C (2011) The role of income in energy consumption behavior: evidence from French households data. Energy Policy 39(12):7874-7883. https://doi.org/10.1016/j. enpol.2011.09.036

Çetinkaya M, Başaran AA, Bağdadioğlu N (2015) Electricity reform, tariff and household elasticity in Turkey. Util Policy 37:79-85

Chamberlain G (1984) Panel data. Handb Econometr 2:1247-1318. https://doi.org/10.1017/cbo9780511814082.011

Chindarkar N, Goyal N (2019) One price doesn't fit all: an examination of heterogeneity in price elasticity of residential electricity in India. Energy Econ 81:765-778. https://doi.org/10. 1016/j.eneco.2019.05.021

Christodoulakis N, Kalyvitis S (1997) The demand for energy in Greece: assessing the effects of the community support framework 1994-1999. Energy Econ 19:393-416. https://doi.org/10. 1016/s0140-9883(97)01013-x

Csereklyei Z (2020) Price and income elasticities of residential and industrial electricity demand in the European Union. Energy Policy 137:111079. https://doi.org/10.1016/j.enpol.2019.111079

Dargay JM (2002) Determinants of car ownership in rural and urban areas: a pseudo-panel analysis. Transp Res E-Log 38(5):351-366. https://doi.org/10.1016/s1366-5545(01)00019-9

Dargay JM, Vythoulkas PC (1999) Estimation of a dynamic car ownership model: a pseudo-panel approach. J Transp Econ Policy 287-301. https://www.jstor.org/stable/20053816

Deaton A (1985) Panel data from time series of cross sections. J Econom 30:109-126. https://doi.org/10.1016/03044076(85)90134-4

Dennerlein RKH (1987) Residential demand for electrical appliances and electricity in the Federal Republic of Germany. Energy J. https://doi.org/10.5547/issn0195-6574-ej-vol8-no1-5

Dergiades T, Tsoulfidis L (2011) Revisiting residential demand for electricity in Greece: new evidence from the ARDL approach to cointegration analysis. Empir Econ 41(2):511-531. https://doi. org/10.1007/s00181-010-0381-8

Díaz AO, Medlock KB (2021) Price elasticity of demand for fuels by income level in Mexican households. Energy Policy 151:112-132. https://doi.org/10.1016/j.enpol.2021.112132

Donatos G, Mergos GJ (1991) Residential demand for electricity: the case of Greece. Energy Econ 13(1):41-47. https://doi.org/10. 1016/0140-9883(91)90054-4

European Commission (2020) Statistical pocketbook 2020. EU energy in figures. https://op.europa.eu/en/publication-detail/-/ publication/87b16988-f740-11ea-991b-01aa75ed71a1/language- 
en?WT.mc_id=Searchresult\&WT.ria_c=37085\&WT.ria_f= $3608 \&$ WT.ria_ev $=$ search

Esmaeilimoakher P, Urmee T, Pryor T, Baverstock G (2016) Identifying the determinants of residential electricity consumption for social housing in Perth. West Aust Energy Build 133:403-413. https://doi.org/10.1016/j.enbuild.2016.09.063

Filippini M, Pachauri S (2004) Elasticities of electricity demand in urban Indian households. Energy Policy 32:429-436. https://doi. org/10.1016/s0301-4215(02)00314-2

Fouquet R (2014) Long-run demand for energy services: income and price elasticities over two hundred years. Rev Environ Econ Policy 8(2):186-207. https://doi.org/10.1093/reep/reu002

Frondel M, Sommer S, Vance C (2019) Heterogeneity in German residential electricity consumption: a quantile regression approach. Energy Policy 131:370-379. https://doi.org/10.1016/ j.enpol.2019.03.045

Garcia-Cerrutti LM (2000) Estimating elasticities of residential energy demand from panel county data using dynamic random variables models with heteroskedastic and correlated error terms. Resour Energy Econ 22(4):355-366. https://doi.org/10.1016/ s0928-7655(00)00028-2

Garders F, Duncan G, Gaubert P, Starzec C (2005) Panel and pseudopanel estimation of cross-sectional and time series elasticities of food consumption: the case of US and polish data. J Bus Econ Stat 23(2):242-253. https://doi.org/10.1198/ 073500104000000587

Gozgor G, Lau CKM, Lu Z (2018) Energy consumption and economic growth: new evidence from the OECD countries. Energy 153:27-34. https://doi.org/10.1016/j.energy.2018.03.158

Hadri K (2000) Testing for stationarity in heterogeneous panel data. J Econometr 3:148-161. https://doi.org/10.1111/1368-423x. 00043

Halicioglu F (2007) Residential electricity demand dynamics in Turkey. Energy Econ 29(2):199-210. https://doi.org/10.1016/j. eneco.2006.11.007

Halvorsen B, Larsen BM (2001) The flexibility of household electricity demand over time. Resour Energy Econ 23(1):1-18. https://doi.org/10.1016/s0928-7655(00)00035-x

Hansen LP (1982) Large sample properties of generalized method of moments estimators. Econometrica 50(4):1029-1054. https://doi. org/10.2307/1912775

Hausman JA (1978) Specification tests in econometrics. Econometrica. https://doi.org/10.2307/1913827

Hellenic Association for Energy Econ-HAEE (2020) Greek energy market report, 2020. https://www.haee.gr/FileServer?file= ca430e84-31ec-4fa8-8153-ac3f6eb16b70

Hellenic Republic (2019) National Energy and Climate Plan-NECP (2019). https://ec.europa.eu/energy/sites/ener/files/el_final_ necp_main_en.pdf

Hellenic Republic (2020) National Recovery and Resilience Plan. Strategic directions of the National Recovery and Resilience Plan. http://www.opengov.gr/minfin/wp-content/uploads/down loads/2020/11/Greece-RRP-EN-1.pdf. Accessed 25 November 2020

Hellenic Statistical Authority (ELSTAT) (2020) General Directorate of Statistical Surveys. http://www.statistics.gr

Hondroyiannis G (2004) Estimating residential demand for electricity in Greece. Energy Econ 26(3):319-334. https://doi.org/10.1016/ s0140-9883(04)00011-8

Holtedahl P, Joutz FL (2004) Residential electricity demand in Taiwan. Energy Econ 26(2):201-224. https://doi.org/10.1016/j. eneco.2003.11.001

Huang WH (2015) The determinants of household electricity consumption in Taiwan: evidence from quantile regression. Energy 87:120-133. https://doi.org/10.1016/j.energy.2015.04. 101
Inglesi-Lotz R (2011) The evolution of price elasticity of electricity demand in South Africa: a Kalman filter application. Energy Policy 39(6):3690-3696. https://doi.org/10.1016/j.enpol.2011. 03.078

IEA (2017) Energy Policies of IEA Countries: Greece 2017 Review. International Energy Agency. https://doi.org/10.1787/ 9789264285316-en

Im KS, Pesaran MH, Shin Y (2003) Testing for unit roots in heterogeneous panels. J Econom 115:53-74. https://doi.org/10. 1016/S0304-4076(03)00092-7

Jones RV, Fuertes A, Lomas KJ (2015) The socio-economic, dwelling and appliance related factors affecting electricity consumption in domestic buildings. Renew Sust Energ Rev 43:901-917. https:// doi.org/10.1016/j.rser.2014.11.084

Jovanović S, Savić S, Bojić M, Djordjević Z, Nikolić D (2015) The impact of the mean daily air temperature change on electricity consumption. Energy 88:604-609. https://doi.org/10.1016/j. energy.2015.06.001

Karatasou S, Laskari M, Santamouris M (2018) Determinants of high electricity use and high energy consumption for space and water heating in European social housing: socio-demographic and building characteristics. Energy Build 170:107-114. https://doi. org/10.1016/j.enbuild.2018.04.019

Kavousian A, Rajagopal R, Fischer M (2013) Determinants of residential electricity consumption: using smart meter data to examine the effect of climate, building characteristics, appliance stock, and occupants' behavior. Energy 55:184-194. https://doi. org/10.1016/j.energy.2013.03.086

Kayalica MO, Ozozen A, Guven D, Kayakutlu G, Bayar AA (2020) Electricity consumption analysis based on Turkish Household Budget Surveys. Energy, Ecol Environ 5(6):444-455. https://doi. org/10.1007/s40974-020-00193-Z

Khanna NZ, Guo J, Zheng X (2016) Effects of demand side management on Chinese household electricity consumption: empirical findings from Chinese household survey. Energy Policy 95:113-125. https://doi.org/10.1016/j.enpol.2016.04.049

Kostakis I (2020) Socio-demographic determinants of household electricity consumption: evidence from Greece using quantile regression analysis. Curr Res Environ Sustain 1:23-30. https:// doi.org/10.1016/j.crsust.2020.04.001

Kraft J, Kraft A (1978) On the relationship between energy and GNP. J Energy Dev 3:401-403. https://www.jstor.org/stable/24806805

Krishnamurthy CKB, Kriström B (2015) A cross-country analysis of residential electricity demand in 11 OECD-countries. Resour Energy Econ 39:68-88. https://doi.org/10.1016/j.reseneeco. 2014.12.002

Labandeira X, Labeaga JM, Rodríguez M (2006) A residential energy demand system for Spain. Energy J. https://doi.org/10.5547/ issn0195-6574-ej-vol27-no2-6

Labandeira X, Labeaga JM, López-Otero X (2017) A meta-analysis on the price elasticity of energy demand. Energy Policy 102:549-568. https://doi.org/10.1016/j.enpol.2017.01.002

Labidi E, Abdessalem T (2018) An econometric analysis of the household direct rebound effects for electricity consumption in Tunisia. Energy Strategy Rev 19:7-18. https://doi.org/10.1016/j. esr.2017.10.006

Lee CC, Chiu YB (2011) Electricity demand elasticities and temperature: evidence from panel smooth transition regression with instrumental variable approach. Energy Econ 33(5):896-902. https://doi.org/10.1016/j.eneco.2011.05.009

Levin A, Lin CF, Chu CSJ (2002) Unit root tests in panel data: asymptotic and finite-sample properties. J Econom 108:1-24. https://doi.org/10.1016/s0304-4076(01)00098-7

Lim KM, Lim SY, Yoo SH (2014) Short- and long-run elasticities of electricity demand in the Korean service sector. Energy Policy 67:517-521. https://doi.org/10.1016/j.enpol.2013.12.017 
Meng Y, Brennan A, Purshouse R, Hill-McManus D, Angus C, Holmes J, Meier PS (2014) Estimation of own and cross price elasticities of alcohol demand in the UK-a pseudo-panel approach using the Living Costs and Food Survey 2001-2009. J Health Econ 34:96-103. https://doi.org/10.1016/j.jhealeco. 2013.12.006

Metcalf GE, Hassett KA (1999) Measuring the energy savings from home improvement investments: evidence from monthly billing data. Rev Econ Stat 81(3):516-528. https://doi.org/10.3386/ w6074

Miller M, Alberini A (2016) Sensitivity of price elasticity of demand to aggregation, unobserved heterogeneity, price trends, and price endogeneity: evidence from US Data. Energy Policy 97:235-249. https://doi.org/10.1016/j.enpol.2016.07.031

Nesbakken R (1999) Price sensitivity of residential energy consumption in Norway. Energy Econ 21(6):493-515. https://doi.org/10. 1016/s0140-9883(99)00022-5

Nickell S (1981) Biases in dynamic models with fixed effects. Econometrica. https://doi.org/10.2307/1911408

Ngui D, Mutua J, Osiolo H, Aligula E (2011) Household energy demand in Kenya: an application of the linear approximate almost ideal demand system (LA-AIDS). Energy Policy 39(11):7084-7094. https://doi.org/10.1016/j.enpol.2011.08.015

O'Connell PG (1998) The overvaluation of purchasing power parity. J Int Econ 44(1):1-19. https://doi.org/10.1016/s00221996(97)00017-2

Okajima S, Okajima H (2013) Estimation of Japanese price elasticities of residential electricity demand, 1990-2007. Energy Econ 40:433-440. https://doi.org/10.1016/j.eneco.2013.07.026

Ozturk I (2010) A literature survey on energy-growth nexus. Energy Policy 38(1):340-349. https://doi.org/10.1016/j.enpol.2009.09. 024

Parti M, Parti C (1980) The total and appliance-specific conditional demand for electricity in the household sector. Bell $\mathrm{J}$ Econ. https://doi.org/10.2307/3003415

Pesaran MH (2004) General diagnostic tests for cross-sectional dependence in panels. Empir Econ. https://doi.org/10.1007/ s00181-020-01875-7

Pesaran MH (2007) A simple panel unit root test in the presence of cross-section dependence. J Appl Econ 22(2):265-312. https:// doi.org/10.1002/jae.951

Polemis ML, Dagoumas AS (2013) The electricity consumption and economic growth nexus: evidence from Greece. Energy Policy 62:798-808. https://doi.org/10.1016/j.enpol.2013.06.086

Rapanos VT, Polemis ML (2005) Energy demand and environmental taxes: the case of Greece. Energy Policy 33(14):1781-1788. https://doi.org/10.1016/j.enpol.2004.02.013

Rehdanz K (2007) Determinants of residential space heating expenditures in Germany. Energy Econ 29(2):167-182. https://doi.org/ 10.1016/j.eneco.2006.04.002

Reiss PC, White MW (2005) Household electricity demand, revisited. Rev Econ Stud 72(3):853-883. https://doi.org/10.1111/00346527.00354

Roodman D (2009) How to do xtabond2: an introduction to difference and system GMM in Stata. Stata J 9(1):86-136. https://doi.org/ 10.1177/1536867x0900900106

Rosas-Flores JA, Bakhat M, Rosas-Flores D, Zayas JLF (2017) Distributional effects of subsidy removal and implementation of carbon taxes in Mexican households. Energy Econ 61:21-28. https://doi.org/10.1016/j.eneco.2016.10.021

Sakah M, du Can SDLR, Diawuo FA, Sedzro MD, Kuhn C (2019) A study of appliance ownership and electricity consumption determinants in urban Ghanaian households. Sustain Cities Soc 44:559-581. https://doi.org/10.1016/j.scs.2018.10.019
Sanquist TF, Orr H, Shui B, Bittner AC (2012) Lifestyle factors in US residential electricity consumption. Energy Policy 42:354-364. https://doi.org/10.1016/j.enpol.2011.11.092

Sargan JD (1958) The estimation of economic relationships using instrumental variables. Econometrica. https://doi.org/10.2307/ 1907619

Schulte I, Heindl P (2017) Price and income elasticities of residential energy demand in Germany. Energy Policy 102:512-528. https:// doi.org/10.1016/j.enpol.2016.12.055

Shin JS (1985) Perception of price when price information is costly: evidence from residential electricity demand. Rev Econ Stat. https://doi.org/10.2307/1924803

Silk JI, Joutz FL (1997) Short and long-run elasticities in US residential electricity demand: a co-integration approach. Energy Econ 19(4):493-513. https://doi.org/10.1016/s01409883(97)01027-x

Sorrell S, Dimitropoulos J (2008) The rebound effect: microeconomic definitions, limitations and extensions. Ecol Econ 65(3):636-649. https://doi.org/10.1016/j.ecolecon.2007.08.013

Stern DI (2004) Economic growth and energy. Encycloped Energy 2:35-51. http://www.sterndavidi.com/Publications/Growth.pdf

Silva S, Soares I, Pinho C (2017) Electricity demand response to price changes: the Portuguese case taking into account income differences. Energy Econ 65:335-342. https://doi.org/10.1016/j. eneco.2017.05.018

Silva S, Soares I, Pinho C (2018) Electricity residential demand elasticities: urban versus rural areas in Portugal. Energy 144:627-632. https://doi.org/10.1016/j.energy.2017.12.070

Sun C, Ouyang X (2016) Price and expenditure elasticities of residential energy demand during urbanization: an empirical analysis based on the household-level survey data in China. Energy Policy 88:56-63. https://doi.org/10.1016/j.enpol.2015. 10.012

Taylor LD (1975) The demand for electricity: a survey. Bell J Econ. https://doi.org/10.2307/3003216

Tiwari P (2000) Architectural, demographic, and economic causes of electricity consumption in Bombay. J Policy Model 22(1):81-98. https://doi.org/10.1016/S0161-8938(98)00003-9

Torgler B, Garcia-Valinas MA (2007) The determinants of individuals' attitudes towards preventing environmental damage. Ecol Econ 63:536-552. https://doi.org/10.1016/j.ecolecon.2006.12. 013

Uhr DDAP, Chagas ALS, Uhr JGZ (2019) Estimation of elasticities for electricity demand in Brazilian households and policy implications. Energy Policy 129:69-79. https://doi.org/10.1016/ j.enpol.2019.01.061

Verbeek M (2008) Pseudo-panels and repeated cross-sections. In: Mátyás L, Sevestre P (eds) The econometrics of panel data. advanced studies in theoretical and applied econometrics, vol 46. Springer, Berlin, Heidelberg. https://doi.org/10.1007/978-3-54075892-1_11

Wiesmann D, Azevedo IL, Ferrão P, Fernández JE (2011) Residential electricity consumption in Portugal: findings from top-down and bottom-up models. Energy Policy 39:2772-2779. https://doi.org/ 10.1016/j.enpol.2011.02.047

Ye Y, Koch SF, Zhang J (2018) Determinants of household electricity consumption in South Africa. Energy Econ 75:120-133. https:// doi.org/10.1016/j.eneco.2018.08.005

Yu Y, Zheng X, Han Y (2014) On the demand for natural gas in urban China. Energy Policy 70:57-63. https://doi.org/10.1016/j.enpol. 2014.03.032

Zhang Y, Ji Q, Fan Y (2018) The price and income elasticity of China's natural gas demand: a multi-sectoral perspective. Energy Policy 113:332-341. https://doi.org/10.1016/j.enpol.2017.11.014 
Zhou S, Teng F (2013) Estimation of urban residential electricity demand in China using household survey data. Energy Policy 61:394-402. https://doi.org/10.1016/j.enpol.2013.06.092
Zonzilos N, Lolos S (1996) Household energy demand in Greece. Discussion paper, National Technical University of Athens (in Greek) 